Proc. Estonian Acad. Sci. Biol. Ecol., 2006, 55, 4, 308-317

\title{
Abundance of willow rust (Melampsora sp.) on different willow clones in Estonian energy forest plantations
}

\author{
Merje Toome*, Katrin Heinsoo, and Anne Luik \\ Institute of Agricultural and Environmental Sciences, Estonian University of Life Sciences, \\ Kreutzwaldi 64, 51014 Tartu, Estonia \\ Received 16 May 2005, in revised form 12 January 2006

\begin{abstract}
The abundance of leaf rust (Melampsora sp.) was assessed on four willow clones in four experimental Estonian willow short-rotation forest plantations. Three plantations were established on poor mineral soil and one was constructed for wastewater purification. Clones 78183 and 81090 were most severely damaged in all four plantations, whereas clones 78021 and 78195 were fairly resistant to rust. In addition to clone type, the number of uredinia on leaves depended on plantation, sampling date, and fertilization. Infection increased significantly during the growing season, and the leaves collected from fertilized plants had more and larger rust pustules than those from unfertilized plants. Uredinia were smaller on older shoots and larger on younger shoots.
\end{abstract}

Key words: rust, disease assessment, Salix viminalis, Salix dasyclados, energy forest plantations.

\section{INTRODUCTION}

Willow plantations are widespread in many European countries, e.g. in the UK, Sweden, and Germany (Royle \& Hubbes, 1992; Larsson, 1998). In northern countries, Salix viminalis L. and S. dasyclados Wimm have been found to be suitable for use as bioenergy sources to provide an alternative to fossil fuels (Johansson \& Alström, 2000). Besides energy production, willows can be used as a vegetation filter in the process of bioremediation of wastewater or contaminated land, and for increasing the content of organic material in soil (McCracken \& Dawson, 1998; Nejad, 2005).

\footnotetext{
*Corresponding author, merje.toome@mail.ee
} 
Monocultures of energy crops are endangered by various diseases and pests. The most widespread and frequent disease in willow plantations is leaf rust, caused by Melampsora spp. Mostly Melampsora larici-epitea, with many pathotypes, parasitizing on different willow clones, is found to cause the greatest damage in energy forest plantations (Pei et al., 1993, 2002; Ramstedt, 1999; Hurtado \& Ramstedt, 2003). This is a leaf infecting form that requires larch (Larix sp. Mill.) as a host for the spring generation (Pei et al., 1993; Ramstedt, 1999). The first infection with leaf rusts occurs usually in late spring when the aeciospores produced on larch spread to willows (Pei et al., 1995; Alexopoulos et al., 1996). Six or seven days after spore germination, the first orange pustules containing urediniospores appear on the lower leaf surface. Urediniospores cycle repeatedly and reinfect willows during the vegetation period, until late autumn when they form teliospores to overwinter on fallen leaves (Pei et al., 1999).

In the case of heavy detriment, the rust fungi may reduce willow biomass production by up to $40 \%$ by damaging leaf tissues and reducing the photosynthesizing area (McCracken \& Dawson, 1998; Pei et al., 2003b). Furthermore, damaged plants may become more susceptible to other pathogens, frost, and other environmental hazards (Verwijst, 1993; Agrios, 1997). In addition to leaf rust, other fungal diseases may cause lesser detriments to willows. In older plantations, willow scab (Fusicladium saliciperdum Lind), branch cankers (Glomerella miyabeana Arx), and stock deforming fungi (Cryptodiaporthe salicella Petr.) have been recorded (Ledin \& Alriksson, 1992; Royle \& Hubbes, 1992; Ramstedt, 1996).

It is extremely important to choose disease-resistant planting material in order to promote high bioenergy production in a willow plantation over several rotation cycles during 20-25 years. The aims of this study were to (1) assess rust damage on different willow clones in Estonian willow plantations under various conditions, (2) reveal the abundance of rust uredinia during the growing season, and (3) estimate the impact of fertilization on leaf rust damage.

\section{MATERIAL AND METHODS}

\section{Willow plantations}

This study was carried out in four Estonian willow plantations. These experimental plantations were established on different soil types, using the willow clones selected within the Swedish Energy Forest Programme (Koppel et al., 1996). In the current study, leaves from three clones of Salix viminalis (according to Swedish clone numbering system clones 78021,78183 , and 78195) and one clone of S. dasyclados (81090) were used. Henceforth, the three last digits of each number (in bold) are used.

Two Saare plantations, established in 1993, are situated on poor mineral soil. The fine pores of the clayey soil supply higher soil horizons with water even 
during drought, but after long rain periods the soil may be too humid. Cuttings were planted in double rows with distances between the rows of 0.75 and $1.5 \mathrm{~m}$, respectively; the distance between plants in a row is $0.5 \mathrm{~m}$. The same planting design was also used in the Nõo plantation (Koppel et al., 1996). One Saare plantation was fertilized annually between 1994 and 2002 with nitrogen $(200 \mathrm{~kg} / \mathrm{ha})$, phosphorous $(25 \mathrm{~kg} / \mathrm{ha})$, and potassium $(50 \mathrm{~kg} / \mathrm{ha})$. In the other Saare plantation no fertilizers were used. The plantations were harvested in 1998 and 2003.

The Nõo plantation was established in 1995 on a flat plateau, previously used as a paddock. The ground contains a generous amount of loam and sand; therefore it can easily desiccate because the large soil pores cannot retain water in the upper layers (Koppel et al., 1996). The plantation was harvested in 2001.

The willow plantation at Aarike was established in 1995 in order to combine wastewater purification and biomass production for energy purposes. Filter beds were planted with willows at a density of two plants per square meter. As a result of good nutrition and water supply, biomass production in the Aarike plantation was about three times higher than in other energy forest plantations in Estonia (Kuusemets \& Mauring, 1996). The plants were last harvested in 2002.

Information on the willow clones used in the plantations, sampling dates, and needle age is presented in Table 1 .

\section{Rust assessments}

Five shoots were randomly selected from every examined plot and 15 full-size leaves were randomly picked from every shoot from the lower leaf horizon of the canopy. The lower horizon was used because rust infection spreads from lower to upper leaves, with lower older leaves being more densely covered with rust uredinia (McCracken \& Dawson, 1992; Åhman, 1997, 1998). Leaves were dried at $65^{\circ} \mathrm{C}$ for two days. Uredinia were counted on dry leaves using a stereomicroscope and the leaf area was assessed with the aid of a computer.

The diameters of uredinia were studied in September 2003. Three leaves were randomly selected from every shoot. On every leaf, the diameter of 20 pustules was measured using a stereomicroscope. The leaf area near midribs and petioles

Table 1. Clones, sampling dates, and age of shoots in four examined sites in 2003

\begin{tabular}{l|l|l|c}
\hline Plantation & \multicolumn{1}{|c|}{$\begin{array}{c}\text { Examined clones } \\
\text { in blocks }\end{array}$} & \multicolumn{1}{|c}{ Sampling date } & $\begin{array}{c}\text { Shoot age, } \\
\text { years }\end{array}$ \\
\hline Saare F+ & $021,183,195,090$ & 31 July, 27 August, 23 September & 1 \\
Saare F- & $021,183,195,090$ & 31 July, 27 August, 23 September & 1 \\
Nõo & $021,183,195,090$ & 24 September & 3 \\
Aarike & 183,090 & 24 September & 2
\end{tabular}


was avoided because pustules tend to be asymmetric in this area (Pei et al., 1995). If there were less than 20 pustules on a leaf, measuring was continued on another leaf picked from the same shoot until 20 uredinia were measured.

\section{Data analysis}

The collected data contained numerous meaningful zeroes, since the leaves were often uninfected with Melampsora. Therefore the variables were non-normally distributed and the assumptions of parametric methods were not met. However, the data included fixed factors, independent observations, and a large randomized sample size that made it possible to use ANOVA methods with the confidence level decreased to 0.01 (Krebs, 1999; Kriisa, 2002). To equalize the variance of the residuals, logarithm transformation was used for counts of uredinia and pustule diameters. To check the reliability of the results obtained by ANOVA, the nonparametric Wilcoxon test was used. The results of the nonparametric test were similar to the ANOVA results.

The effect of different factors on the number of uredinia per leaf area was analysed using General Linear Models in SAS 8.02. Differences in clone, plantation, fertilization, and sampling time were detected with the Scheffe test.

\section{RESULTS}

In the Saare plantations, willow clone, leaf sampling date, and fertilization correlated with the number of rust pustules. Fertilization increased the diameters of uredinia. Both clone and plantation factors had significant effects on the number and size of uredinia.

\section{Clone 021 (S. viminalis)}

Clone 021 was moderately susceptible to leaf rust, bearing on average 5.4 uredinia per unit leaf area in September 2003. The leaves were not infected with leaf rust in July and beared few pustules in August. In Saare fertilized plants $(\mathrm{F}+)$ the infection rate rose in September and the leaves from clone 021 were moderately infected at the end of the vegetation period $(p<0.001)$. In Saare unfertilized plants $(\mathrm{F}-)$ the leaves were only slightly infected through the year $(p>0.01)$ (Fig. 1). Uredinia on the leaves of fertilized plants were larger $(p<0.01)$. In the Nõo plantation, clone 021 had more but smaller rust pustules than in the Saare plantations at the same time $(p<0.001)$ (Figs 2 and 3). 
Saare F-

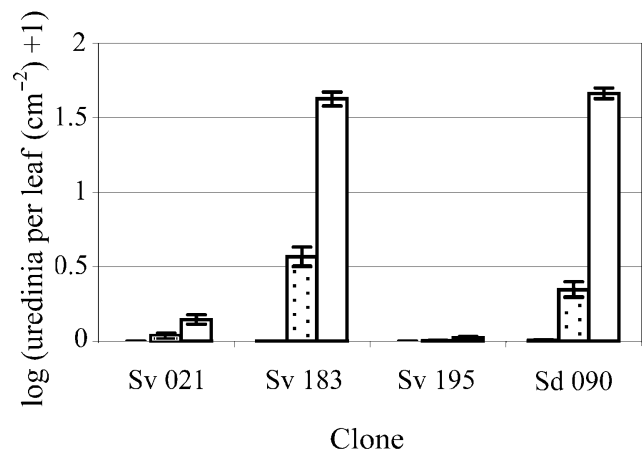

Saare F+

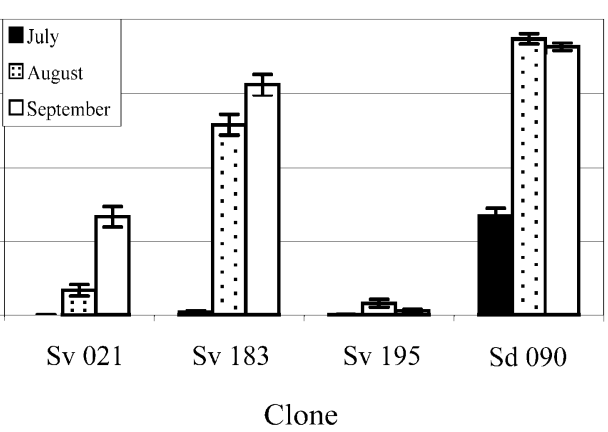

Fig. 1. Mean number of pustules per leaf area unit (logarithm-transformed) with standard errors, recorded on three different dates (31 July, 27 August, 23 September 2003) and on four different willow clones in sites Saare F- (unfertilized) and Saare F+ (fertilized) (absent bars implicate the meaningful zeros (no uredinia on leaves)). $\mathrm{Sv}-\mathrm{S}$. viminalis, $\mathrm{Sd}-\mathrm{S}$. dasyclados.

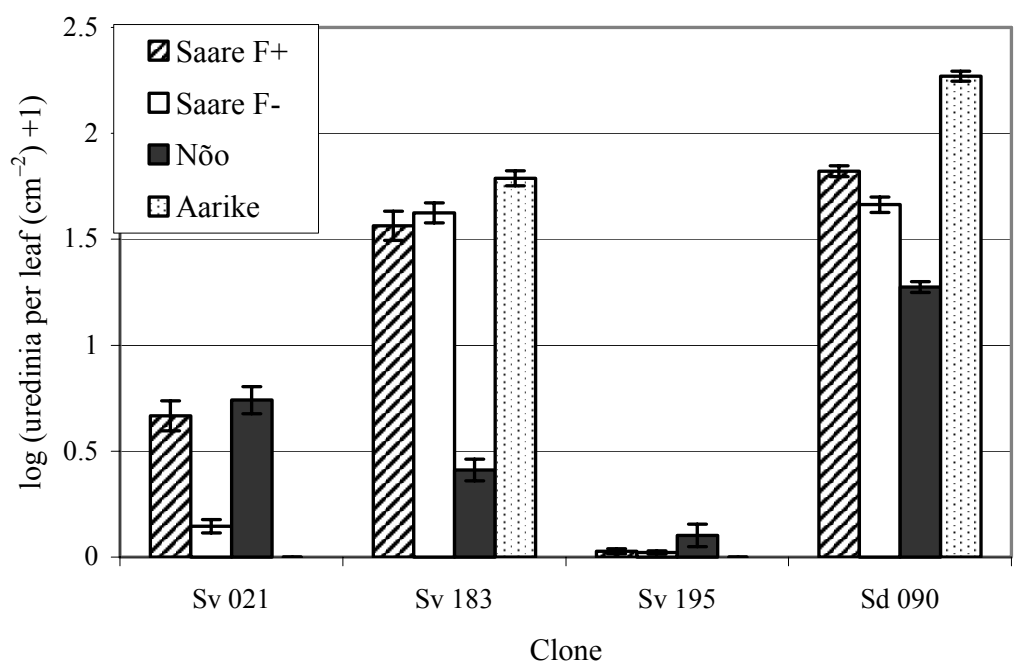

Fig. 2. Mean number of pustules per leaf area unit (logarithm-transformed) with standard errors, recorded on different clones in four different sites (Saare F+ (fertilized), Saare F- (unfertilized), Nõo, and Aarike). Clones 021 and 195 were not present in the Aarike plantation. Sv - S. viminalis, $\mathrm{Sd}-\mathrm{S}$. dasyclados. 


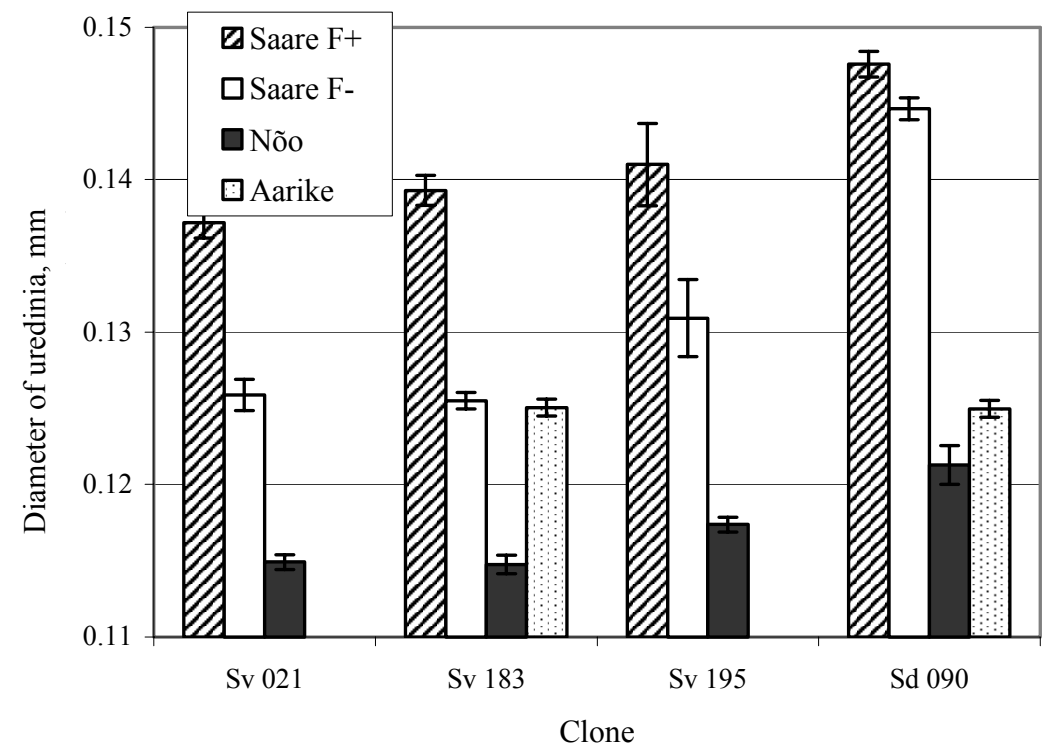

Fig. 3. Mean rust pustule diameters with standard errors on different clones measured on willow leaves in four sites (Saare F+ (fertilized), Saare F- (unfertilized), Nõo, and Aarike). Clones 021 and 195 were not present in the Aarike plantation. $\mathrm{Sv}-$ S. viminalis, $\mathrm{Sd}-\mathrm{S}$. dasyclados.

\section{Clone 183 (S. viminalis)}

Clone 183 was the most rust susceptible of the $S$. viminalis clones studied, having on average 46.3 uredinia per unit leaf area. In both Saare plantations the infection in July was slight but in August pustules were numerous on leaves, the number of rust pustules increased further in September $(p<0.001)$. The fertilized plants were more infected than the unfertilized plants $(p<0.001)$ in July and August (Fig. 1). This clone had a similar infection rate in the Aarike and Saare plantations; plants were less infested in the Nõo plantation $(p<0.001)$ (Fig. 2). Leaves were bearing the largest pustules in the Saare plantations, whereas uredinia were significantly smaller in the Aarike and Nõo plantations (Fig. 3).

\section{Clone 195 (S. viminalis)}

Among the studied clones, clone 195 was found to be the most resistant to leaf rust in 2003. On average there were only 0.3 rust uredinia per unit leaf area in September. In the Saare plantations the leaves had very few uredinia throughout the vegetation period (Fig. 1). The infection rate in all studied sites was not different $(p>0.01)$ (Fig. 2), although pustules were smaller at Nõo $(p<0.01)$ (Fig. 3). 


\section{Clone 090 ( $S$. dasyclados)}

Of all the studied clones, clone 090 was the most susceptible to rust. In September one leaf unit was, on average, covered with 98 pustules. The onset of the disease in Saare F+ was recorded at a moderate rate already in July and it increased significantly in August and September $(p<0.001)$. Fertilization increased significantly the number of uredinia in July and August $(p<0.001)$, but in September the leaves both in Saare F+ and F- were heavily infected $(p>0.01)$ (Fig. 1). The most infected plants of this clone were growing in the Aarike plantation, followed by the Nõo and Saare plantations $(p<0.001)$ (Fig. 2). The largest pustules were recorded in the Saare plantations $(p<0.001)$, followed by the Aarike and Nõo plantations, with the same average pustule size $(p>0.05)$ (Fig. 3).

\section{DISCUSSION}

This study confirms the results of earlier studies, revealing S. dasyclados clone 090 to be very susceptible to leaf rust (Pei et al., 1999; Peacock et al., 2001). Infection of clone 090 may differ annually because $S$. dasyclados is more sensitive to weather conditions than other willow species (Johansson \& Alström, 2000). The wet and cool early summer of 2003 (Keppart, 2003) explains the early appearance of Melampsora sp. on the leaves of clone 090. In addition to weather conditions leaf construction may affect the infection by leaf rust. The leaves of $S$. dasylados are covered with rarefied trichomes, compared with dense trichomes on the leaves of $S$. viminalis. Dense trichomes protect the leaf surface against pathogens (Bennett \& Wallsgrove, 1994).

Among $S$. viminalis clones the plants from clone 195 were nearly resistant, clone 021 moderately infected, and clone 183 strongly diseased. In Sweden clones 021 and 195 were equally susceptible to leaf rust and clone 183 was the most receptive $S$. viminalis clone (Ledin \& Alriksson, 1992). Despite its low rust resistance, clone 183 is still one of the most commonly planted clones in willow plantations because of its frost resistance and high productivity (Larsson, 1998).

This study reveals that the majority of willow leaves in the Saare energy crop plantations were not infected in July; only clone 090 had rust damage. The late appearance of leaf rust may be explained by the fact that no alternate host has been found near the Saare plantations. Therefore the first rust spores have to disperse to willow leaves from longer distances, and infection occurs later. The abundance of rust increased during the growing season and achieved a maximum in September, when the number of uredinia had at least tripled. The same observations about rust occurrence and distance between alternate host and plantation have been made before in other studies (McCracken \& Dawson, 1997; Larsson, 1998; Samils et al., 2001). 
Willow plants were more infected in the Aarike wastewater purification plantation than in the Nõo and Saare plantations, which were established on poor mineral soils. Leaves on fertilized plants in the Saare plantation were generally more damaged than on unfertilized plants. This indicates that plants with a good nutrient supply are more infected by rust fungi than in poor habitats. For instance, because of morphophysiological transformations in leaves, the twisting rust fungus (Melampsora pinitorqua) on pine damages fertilized plants the most (DesprezLoustau \& Wagner, 1997). Plants invest less in leaf protecting chemicals in better nutrient and water conditions, causing higher susceptibility to plant pathogens (Bennett \& Wallsgrove, 1994).

Larger uredinia always contain more rust spores than smaller ones, which promotes mostly the distribution speed of the disease. Therefore it is important to evaluate the size of uredinia (Pei et al., 2003b). Although fertilization had a considerable effect on pustule size, only clone 021 had larger pustules on the leaves of fertilized plants. In the Saare plantations the willow shoots were one year old and there the pustules were the largest, in the Nõo plantation the shoots were three years old and the pustules were the smallest. In the Aarike plantation the shoots were two years old and the uredinia had an intermediate size. Differences in the size of uredinia may be associated with the age of shoots or with microclimatic conditions in different plantations. Desprez-Loustau \& Wagner (1997) demonstrated higher resistance to rust with plant ageing and therefore young plants should bear more and larger rust pustules. To evaluate the impact of shoot age on the leaf rust abundance, long-term studies are needed.

Because of economic, technical, and environmental considerations, control of leaf rust by fungicides is not favoured. Alternative methods, including biological control, are thought to be a better choice (Pei et al., 1996, 2003a). The leaf rust antagonist Eudarluca caricis (anamorph Sphaerellopsis filum) was found on leaves in the Saare plantations in September, where the parasite had spread almost to all rust pustules (M. Toome, unpublished data). Eudarluca caricis reduces the distribution of leaf rust in summer, diminishing spore production by up to $94 \%$ (Pei et al., 2003a).

The present study indicates that considering rust infection clones 021 and 195 are suitable for new willow plantations in Estonia. However, clone 195 is no longer used in Estonian plantations because of its frost susceptibility (Heinsoo et al., 2002). Long-term monitoring in Estonian willow plantations is necessary, because rust infection may vary annually.

\section{ACKNOWLEDGEMENTS}

We are grateful to Toomas Tammaru, Kadri Lõbus, and Leho Tedersoo for advice on statistical data analysis. Triin Tilger and Siret Tappo assisted in the fieldwork. The study was partly funded by the grant ETF 4831 of the Estonian Science Foundation. 


\section{REFERENCES}

Agrios, G. N. 1997. Plant Pathology, 4th edn. Academic Press, USA.

Åhman, I. 1997. Growth, herbivory and disease in relation to gender in Salix viminalis L. Oecologia, 111, 61-68.

Åhman, I. 1998. Rust scorings in plantation of Salix viminalis clones during ten consecutive years. Eur. J. For. Pathol., 28, 251-258.

Alexopoulos, C. J., Mims, C. W. \& Blackwell, M. 1996. Introductory Mycology, 4th edn. John Wiley \& Sons, USA.

Bennett, R. N. \& Wallsgrove, R. M. 1994. Secondary metabolites in plant defence mechanisms. New Phytol., 127, 617-633.

Desprez-Loustau, M.-L. \& Wagner, K. 1997. Influence of silvicultural practices on twisting rust infection and damage in maritime pine, as related to growth. For. Ecol. Manage., 98, 135147.

Heinsoo, K., Sild, E. \& Koppel, A. 2002. Estimation of shoot biomass productivity in Estonian Salix plantations. For. Ecol. Manage., 170, 67-74.

Hurtado, S. P. \& Ramstedt, M. 2003. Comparing Chilean and Swedish rust populations: possible impact of long-distance transport of Melampsora rust. For. Pathol., 33, 69-80.

Johansson, L. K.-H. \& Alström, S. 2000. Field resistance to willow leaf rust Melampsora epitea in inter- and intraspecific hybrids of Salix viminalis and S. dasyclados. Eur. J. For. Pathol., 106, 763-769.

Keppart, L. 2003. 2003. a. agrometeoroloogilised tingimused Jõgeval. Available online: www.sordiaretus.ee/files/Agrometeoroloogia/2003.pdf (visited 4.09.2006).

Koppel, A., Perttu, K. \& Ross, J. 1996. Estonian energy forest plantations - general information. In Short Rotation Willow Coppice for Renewable Energy and Improved Environment (Perttu, K. \& Koppel, A., eds), pp. 15-42. Swedish University of Agricultural Sciences, Uppsala.

Krebs, C. J. 1999. Ecological Methodology. 2nd edn. Addison-Welsey Educational Publishers, USA.

Kriisa, T. 2002. Dispersioonanalüüsi eelduste mõju F-testile. Diploma thesis. University of Tartu, Tartu, Estonia.

Kuusemets, V. \& Mauring, T. 1996. Wastewater purification in a willow plantation. The case study at Aarike. In Short Rotation Willow Coppice for Renewable Energy and Improved Environment (Perttu, K. \& Koppel, A., eds), pp. 159-165. Swedish University of Agricultural Sciences, Uppsala.

Larsson, S. 1998. Genetic improvement of willow for short-rotation coppice. Biomass Bioenergy, $15,23-26$.

Ledin, S. \& Alriksson, A. 1992. Handbook on How to Grow Short Rotation Forests. Swedish University of Agricultural Sciences, Uppsala.

McCracken, A. R. \& Dawson, W. M. 1992. Clonal response in Salix to Melampsora rusts in short rotation coppice plantations. Eur. J. For. Pathol., 22, 19-28.

McCracken, A. R. \& Dawson, W. M. 1997. Growing clonal mixtures of willow to reduce effect of Melampsora epitea var. epitea. Eur. J. For. Pathol., 27, 319-329.

McCracken, A. R. \& Dawson, W. M. 1998. Short rotation coppice willow in Northen Ireland since 1973: development of the use of mixtures in the control of foliar rust (Melampsora spp.). Eur. J. For. Pathol., 28, 241-251.

Nejad, P. 2005. Pathogenic and Ice-Nucleation Active (INA) Bacteria Causing Dieback of Willows in Short Rotation Forestry. Doctoral thesis. Swedish University of Agricultural Sciences, Uppsala.

Peacock, L., Hunter, T., Turner, H. \& Brain, P. 2001. Does host genotype diversity affect the distribution of insect and disease damage in willow cropping systems? J. Appl. Ecol., 38, 1070-1081.

Pei, M. H., Royle, D. J. \& Hunter, T. 1993. Identity and host alternation of some willow rusts (Melampsora spp.) in England. Mycol. Res., 97, 845-851. 
Pei, M. H., Royle, D. J. \& Hunter, T. 1995. A comparative study of stem- and leaf-infecting forms of Melampsora rust on Salix viminalis in the U.K. Mycol. Res., 99, 357-363.

Pei, M. H., Royle, D. J. \& Hunter, T. 1996. Pathogenic specialization in Melampsora epitea var. epitea on Salix. Plant Pathol., 45, 679-690.

Pei, M. H., Hunter, T. \& Ruiz, C. 1999. Occurrence of Melampsora rusts in biomass willow plantations for renewable energy in the United Kingdom. Biomass Bioenergy, 17, 153-163.

Pei, M. H., Ruiz, C., Hunter, T., Arnold, G. M. \& Bayon, C. 2002. Quantitative relationships between inoculum of Melampsora larici-epitea and corresponding disease on Salix. Plant Pathol., 51, 443-453.

Pei, M. H., Hunter, T., Ruiz, C., Bayon, C. \& Harris, J. 2003a. Quantitative inoculation of willow rust Melampsora larici-epitea with the mycoparasite Sphaerellopsis filum (teleomorph Eudarluca caricis). Mycol. Res., 107, 57-63.

Pei, M. H., Ruiz, C., Hunter, T. \& Bayon, C. 2003b. Rust resistance in Salix induced by inoculations with avirulent and virulent isolates of Melampsora larici-epitea. For. Pathol., 33, 383-394.

Ramstedt, M. 1996. Plant protection in short rotation forestry against fungi and bacteria. In The Swedish Energy Forestry Research Programme at the Department of Short Rotation Forestry, Suas, Uppsala (Ledin, S. \& Christersson, L., eds), pp. 115-124. Swedish University of Agricultural Sciences, Uppsala.

Ramstedt, M. 1999. Rust disease on willows - virulence variation and resistance breeding strategies. For. Ecol. Manage., 121, 101-111.

Royle, D. J. \& Hubbes, M. 1992. Diseases and pests in energy crop plantations. Biomass Bioenergy, 2, 45-54.

Samils, B., Stepien, V., Lagercrantz, U. \& Lascoux, M. 2001. Genetic diversity in relation to sexual and asexual reproduction in populations of Melampsora larici-epitea. Eur. J. For. Pathol., 107, 871-881.

Verwijst, T. 1993. Influence of the pathogen Melampsora epitea on intraspecific competition in mixture of Salix viminalis clones. J. Veget. Sci., 4, 717-722.

\title{
Paju-pigirooste (Melampsora sp.) arvukus erinevatel pajukloonidel Eesti istandustes
}

\author{
Merje Toome, Katrin Heinsoo ja Anne Luik
}

On hinnatud paju-pigirooste arvukust neljal erineval pajukloonil neljas Eesti energiavõsa istanduses. Kõige rohkem on roosteseenega nakatunud kloonide 78183 ja 81090 lehed, kusjuures kloonid 78021 ja 78195 on peaaegu resistentsed. Pigiroosteeoslate arvukus lehel sõltub lisaks kloonile ka istandusest, proovivõtu ajast ja väetamisest. Roosteeoslate arv suureneb kasvuperioodi jooksul ja väetatud taimede lehed on rohkem nakatunud kui väetamata taimedel. Vanematel taimedel on väiksemad ja noorematel suuremad pigiroosteeoslad. 